\title{
BERDUKA PADA PEREMPUAN HIV POSITIF
}

\author{
Rizka Ristriyani, Imami Nur Rachmawati*, Yati Afiyanti
}

Fakultas Ilmu Keperawatan Universitas Indonesia, Depok 16424, Indonesia

*E-mail: inrachma@ui.ac.id

\begin{abstract}
Abstrak
HIV sebagai penyakit kronis dapat mengubah kualitas hidup penderitanya. Penelitian ini bertujuan untuk mengidentifikasi intensitas respon berduka pada perempuan HIV positif. Rancangan penelitian menggunakan survey dengan metode pengambilan sampel secara consecutive sampling. Jumlah sampel penelitian sebanyak 235 perempuan HIV positif yang menjadi pasien di beberapa Puskesmas di Jakarta, Indonesia. Hasil penelitian didapatkan gambaran denial dengan nilai tengah yaitu 2,25 (SD 0,75) berada pada rentang 2,18-2,38; resistance dengan nilai tengah yaitu 1,67 (SD 0,89 ) berada pada rentang 1,84-2,07; sorrow dengan nilai tengah yaitu 2,67 (SD 0,93) berada pada rentang 2,26-2,52; dan acceptance dengan nilai tengah yaitu 3 (SD 0,72) berada pada rentang 2,79-2,98 pada tingkat kepercayaan $95 \%$. Karakteristik responden menunjukkan bahwa lebih dari separuh responden adalah ibu rumah tangga $(65,5 \%)$, menikah sebanyak 56,2\% dan 50\% responden menyatakan tertular HIV dari pasangannya. Usia termuda pada penelitian ini adalah 18 tahun dan yang tertua adalah 47 tahun. Penelitian ini menemukan bahwa sikap menyangkal perempuan HIV positif berada pada skala sedang, kemarahan pada skala ringan, kesedihan mendalam pada skala sedang, dan penerimaan pada skala mendekati penuh. Karakteristik responden seluruhnya berasal dari fasilitas kesehatan primer yang telah mendapatkan pengobatan dan konseling sehingga hal tersebut mendukung acceptance yang penuh pada responden. Namun demikian masih perlu penelitian lebih lanjut mengenai factor-faktor yang memengaruhi berduka pada perempuan HIV positif.
\end{abstract}

Kata Kunci: penerimaan, berduka, menyangkal, perempuan HIV, marah, kesedihan mendalam

\begin{abstract}
The Grieving Process of The HIV-Positive Women. HIV as a chronic disease can change the quality of life of sufferers. This study aimed to identify the intensity of grief response in HIV-positive women. The study was a survey which applied a consecutive sampling to involve 235 HIV positive women. The women were at a Community Health Center in Jakarta, Indonesia. The result showed that a mean value of denial was 2.25 (SD 0.75) in the range of 2.18 to 2.38; a mean value of resistance was 1.67 (SD 0.89) in the range of 1.84-2.07; the middle value of sorrow was 2.67 (SD 0.93) in the range 2.26 -2.52; and the mean value of acceptance was 3 (SD 0.72) in the range 2.79-2.98 at the $95 \%$ confidence level. Characteristics of respondents shows that more than half of respondents were housewives (65.5\%), married $56.2 \%$ and $50 \%$ of respondents said that they contracted HIV from their spouses. The youngest age in this study was 18 years old, and the eldest was 47 years old. The study found that the attitudes of denying was on a moderate scale, anger on a mild scale, sorrow on a moderate scale, and acceptance on near-fullness scale. All of respondents was patient in Primary Care Facilities who receive medication and counseling that might be one of the factors that cause full acceptance of the disease condition. However, further research is needed to identify factors influencing the grieving process of the HIV-positive women.
\end{abstract}

Keywords: acceptance, denial, grieving, resistance, sorrow, HIV women

\section{Pendahuluan}

World Health Organization (2015) menyatakan terdapat 16 juta perempuan HIV positif atau $50 \%$ dari total penderita HIV AIDS di dunia.
Sebaliknya, Direktorat Jenderal Pengendalian Penyakit dan Penyehatan Lingkungan (P2PL) Kementerian Kesehatan Republik Indonesia menyebutkan jumlah orang terinfeksi HIV lebih banyak 1,3 kali pada laki-laki dibanding- 
kan perempuan, namun jumlah kumulatif penderita AIDS berdasar jenis pekerjaan ditemukan tertinggi pada kelompok ibu rumah tangga sebanyak 6539 orang (Kementerian Kesehatan, 2014). Berdasarkan data tersebut, penyebaran HIV pada perempuan tergolong mengkhawatirkan karena telah menyebar pada kelompok yang tidak berisiko seperti ibu rumah tangga dan anak-anak.

Diagnosa medis HIV positif, kehilangan kesehatan dan kesempatan memiliki anak yang sehat dapat menyebabkan berduka pada perempuan HIV positif. Damar dan du Plessis (2010) menyatakan ibu hamil dengan HIV positif berduka karena tertular HIV dari suaminya dengan bereaksi marah kepada Tuhan. Dewi, Setyowati, dan Afiyanti (2008) menyatakan perempuan hamil yang terdiagnosa HIV positif cemas akan keselamatan janinnya. Berduka pada perempuan HIV positif juga dapat terjadi ketika pasangan, anak, atau keluarganya meninggal karena AIDS. Demmer (2010) menyatakan seorang ibu harus menahan dukanya kehilangan anak yang meninggal dan berjuang menghidupi anaknya yang lain. Berdasarkan hal tersebut, perempuan HIV positif dapat mengalami kehilangan dan proses berduka lebih dari satu kehilangan (multiple loss).

Beberapa penelitian sebelumnya telah membahas secara kualitatif mengenai berduka pada pasien HIV AIDS namun masih terdapat keterbatasan mengenai intensitas dari masing-masing respon berduka yang dialami oleh kelompok spesifik, yakni perempuan HIV positif. Oleh karena itu tujuan penelitian ini adalah untuk mengetahui gambaran tahapan berduka yang dialami perempuan HIV positif.

\section{Metode}

Penelitian survai ini melibatkan sampel sebanyak 235 perempuan HIV positif. Consecutive sampling diterapkan pada responden dengan kriteria inklusi perempuan HIV positif, dalam kondisi umum yang baik, dalam pengobatan Antiretroviral (ARV), dan sukarela menjadi responden. Analisis data pada penelitian yaitu univariat. Adapun instrumen yang digunakan antara lain data demografi, kuesioner modifikasi Acceptance of Disease and Impairments Questionnaire (ADIQ) dari Boer, et al., (2014). Penelitian ini telah mendapatkan persetujuan etik dari Komite Etik Fakultas Ilmu Keperawatan Universitas Indonesia.

Orang dengan HIV AIDS (ODHA) mudah mendapatkan pengobatan dan konseling di Poli Voluntary Counseling and Testing (VCT) di Puskesmas sehingga responden mudah terjaring. Oleh sebab itu tempat pelaksanaan penelitian dilakukan di Puskesmas Kecamatan di lima wilayah Kotamadya DKI Jakarta, Indonesia.

\section{Hasil}

Tabel 1 menggambarkan intensitas respon berduka pada perempuan HIV positif. Tabel 2 menggambarkan karakteristik responden.

Tabel 1. Nilai Tengah Denial, Resistance, Sorrow, dan Acceptancepada Perempuan HIV Positif

\begin{tabular}{lccc}
\hline \multicolumn{1}{c}{ Variabel } & Median & SD & CI 95\% \\
\hline Denial & 2,25 & 0,75 & $2,18-2,38$ \\
Resistance & 1,67 & 0,89 & $1,84-2,07$ \\
Sorrow & 2,67 & 0,93 & $2,26-2,52$ \\
Acceptance & 3 & 0,72 & $2,79-2,98$ \\
\hline
\end{tabular}


Tabel 2. Distribusi Frekuensi Menurut Jenis Pekerjaan, Pendapatan, Status Pernikahan, Status HIV Pasangan, Sumber Penularan, dan Lama Mengetahui pada Perempuan HIV Positif

\begin{tabular}{lc}
\hline \multicolumn{1}{c}{ Variabel } & Persentase (\%) \\
\hline Jenis Pekerjaan & 65,5 \\
a. Ibu rumah tangga & 8,5 \\
b. Wiraswasta & 18,7 \\
c. Karyawan & 0,9 \\
d. Pekerja informal & 6,4 \\
e. Lain-lain & \\
Pendapatan & 74,9 \\
a. Kurang dari upah minimum regional & 25,1 \\
b. Lebih dari sama dengan upah minimum regional & \\
& \\
Status Pernikahan & 8,5 \\
a. Tidak menikah & 56,2 \\
b. Menikah & 14 \\
c. Janda karena cerai & 21,3 \\
d. Janda karena suami meninggal & \\
Status HIV pasangan & 60,4 \\
a. Positif & 11,5 \\
b. Negatif & 28,1 \\
c. Belum diketahui & \\
Sumber penularan & \\
a. NAPZA dengan jarum suntik & 20,9 \\
b. Transfusi darah & 1,7 \\
c. Pasangan terinfeksi lebih dahulu & 50,2 \\
d. Berhubungan seksual dengan lebih dari satu pasangan & 11,1 \\
e. Tidak tahu & 16,2 \\
& \\
Lama mengetahui terinfeksi HIV & \\
a. Kurang dari 12 bulan & 25,5 \\
b. Lebih dari 12 bulan & 74,5 \\
\hline
\end{tabular}

Tabel 1 menunjukkan bahwa subvariabel denial dengan nilai tengah 2,25 dengan tingkat kepercayaan $95 \%$ berada pada estimasi rentang 2,18-2,3 menunjukkan bahwa sikap menyangkal yang ditunjukkan perempuan HIV positif berada pada skala sedang. Subvariabel resistance dengan nilai tengah 1,67 dengan tingkat kepercayaan $95 \%$ berada pada estimasi rentang 1,84-2,07 sehingga dapat diartikan bahwa sikap marah perempuan HIV positif berada pada skala yang rendah. Subvariabel sorrow dengan nilai tengah 2,67 dengan tingkat kepercayaan $95 \%$ berada pada estimasi rentang 2,26-2,52, artinya perempuan HIV positif mengalami kesedihan pada skala sedang. Adapun subvariabel acceptance dengan nilai tengah 3 dengan tingkat kepercayaan $95 \%$ berada pada estimasi rentang 2,79-2,98 menunjukkan sikap penerimaan perempuan akan status HIV positifnya mendekati penerimaan penuh.

\section{Pembahasan}

Fase Denial. Kubler Ross dalam Videbeck (2011) menyatakan tahapan berduka meliputi menyangkal, marah, tawar-menawar, depresi, dan menerima. Sikap menyangkal sebagai salah satu respon berduka dapat disebabkan berbagai faktor. Hasil penelitian ini menemukan responden mengalami penyangkalan dalam 
skala sedang. Secara umum, ketika individu terdiagnosis penyakit akan mengalami kehilangan dan proses berduka.

Penelitian sebelumnya menyebutkan bahwa penderita HIV positif dapat menyangkal status HIV positifnya karena tidak merasakan gejala keparahan penyakit HIV AIDS (Wringe, et al., 2009). Hal tersebut sejalan dengan hasil penelitian menemukan bahwa mayoritas responden hanya merasakan gejala HIV dengan intensitas ringan seperti sakit kepala, kelelahan, penurunan berat badan, gangguan ginekologi, dan sebagainya. Kondisi demikian dapat menyebabkan perempuan HIV positif tidak merasakan suatu penyakit yang mengganggu fungsi tubuhnya sehingga memuncukan sikap menyangkal akan status HIV positif.

Selain itu, penderita HIV positif menyangkal statusnya juga disebabkan oleh malu yang berhubungan dengan HIV AIDS. Penelitian sebelumnya menemukan bahwa malu dan tidak nyaman membicarakan tentang HIV AIDS dikarenakan sikap menyangkal (Piper, Enah, \& Daniel, 2014). Malu yang berhubungan dengan HIV AIDS dapat disebabkan oleh stigma HIV di masyarakat yang mengaitkan antara sumber penularan HIV AIDS dengan prostitusi dan pelanggaran norma moral.

Dahulu penularan HIV AIDS terjadi pada kelompok populasi kunci seperti wanita pekerja seks (WPS) dan pengguna jarum suntik (penasun). Namun demikian, beberapa dekade terakhir penularan HIV AIDS telah meluas kepada kelompok bukan populasi kunci seperti ibu rumah tangga dan anak yg merasa sebagai individu yang selalu menjaga norma moral (Rahmalia, et al., 2015).

Hasil penelitian ini diketahui bahwa mayoritas responden adalah ibu rumah tangga yang sumber penularan HIV didominasi oleh hubungan seksual dengan suami. Oleh karena itu, mayoritas responden pada penelitian ini dapat menyangkal akan statusnya karena malu dan stigma HIV di masyarakat.
Ibu rumah tangga cenderung tidak mengetahui jika suaminya terinfeksi HIV positif sehingga dapat mengakibatkan penyangkalan ketika dirinya pun terinfeksi HIV positif dari suami. Kondisi demikian sesuai dengan penelitian sebelumnya yang menyebutkan bahwa perempuan baru mengetahui dirinya terinfeksi HIV positif dari suaminya setelah suaminya terjangkit AIDS dan menyebabkan sikap marah dan menyangkal (Damar \& du Plessis, 2010).

Fase Resistance. Penelitian ini menemukan bahwa sikap marah perempuan karena terinfeksi HIV positif berada pada level rendah. Kondisi demikian dapat disebabkan karena perempuan cenderung menahan kemarahannya dan memilih untuk melanjutkan tugas merawat suami dan anaknya. Penelitian sebelumnya menyebutkan norma di masyarakat mewajibkan perempuan untuk mengabdi kepada suami termasuk merawat suami yang sakit, oleh karena itu mayoritas perempuan merasa tidak tepat untuk meluapkan kemarahannya kepada suami yang terbaring tidak berdaya karena AIDS (Damar \& du Plessis, 2010).

Selain itu hasil penelitian menemukan bahwa semakin banyak jumlah anak yang dimiliki maka semakin berkurang marah pada perempuan HIV positif. Semakin banyak anak yang dimiliki maka fokus dan waktu seorang ibu lebih diutamakan untuk merawat anaknya dibanding untuk marah karena terinfeksi HIV positif. Walulu (2007) menyatakan memiliki anak merupakan motivasi utama bagi perempuan HIV untuk serius merawat diri mereka sendiri, hidup sehat dan positif sehingga dapat merawat anak mereka sebaik mungkin kemudian. Perempuan HIV lebih memikirkan siapa yang akan merawat anaknya nanti apabila mereka sakit daripada terus dihinggapi kemarahan dan kesedihan (Damar \& du Plessis, 2010).

Hal ini mencerminkan bahwa perempuan dapat teralihkan marahnya karena lebih penting untuk tugas merawat keluarga. Hasil ini sejalan dengan penelitian sebelumnya yang menyatakan bahwa perempuan SubSahara Afrika yang ter- 
infeksi HIV positif memendalam perasaannya dan lebih mementingkan merawat anak yang masih hidup di lingkungan yang kekurangan sumber daya dan tingginya stigma (Demmer, 2010).

Selain karena nilai merawat keluarga, perempuan juga memiliki nilai menerima keadaan yang disebut dengan takdir. Penelitian sebelumnya menyebutkan bahwa perempuan HIV positif awalnya bereaksi marah mempertanyakan Tuhan mengenai takdir namun akhirnya perempuan meresapi dan menerima takdir Tuhan yang tidak bisa diubah (Damar \& du Plessis, 2010; Kaplan, 2011).

Kondisi demikian dapat didukung dengan kondisi spiritual yang baik. Hasil penelitian menunjukkan mayoritas responden beribadah rutin setiap hari dan menyatakan setuju untuk mengampuni sesama. Bekal keyakinan akan adanya Tuhan dan sikap memaafkan pada hasil penelitian dapat menurunkan resistance pada perempuan HIV positif.

Penelitian sebelumnya menemukan bahwa sikap marah masih dapat dikontrol berhubungan signifikan dengan kepatuhan pengobatan, sebaliknya pasien yang mudah untuk marah dan tidak mampu mengontrol kemarahan menyebabkan tidak patuh pengobatan (Leombruni, et al., 2009). Sementara sikap marah dapat diturunkan dengan intervensi koping penerimaan positif pada penderita HIV positif (Bormann \& Carrico, 2009).

Fase Sorrow. Sorrow pada penelitian ini berada pada skala sedang, hal tersebut dapat disebabkan mayoritas responden adalah ibu rumah tangga yang menyatakan setuju telah mengalami kesedihan mendalam karena terinfeksi HIV positif. Populasi kunci seperti wanita pekerja seks (WPS) telah mengetahui bahwa pekerjaannya berisiko terinfeksi HIV AIDS sehingga WPS berpeluang mengantisipasi berduka (antipatory grief). Berbeda dengan ibu rumah tangga yang tidak pernah berperilaku berisiko dan tidak pernah me- nyangka akan terinfeksi HIV sehingga respon menyangkal dan depresi lebih sering ditunjukkan oleh mayoritas kelompok ibu rumah tangga.

Kesedihan dan depresi yang diidentifikasi pada penelitian masih dalam respon normal dan berskala sedang. Apabila skala yang ditunjukkan pada depresi adalah intensitas berat maka umumnya pasien tidak mampu mengerjakan aktivitas kesehariannya dan larut dalam kesedihannya serta tidak mampu berkomunikasi efektif dengan orang lain. Videbeck (2011) menyatakan pasien dengan gejala depresi mayor bahkan tidak ingin bangun dari tempat tidurnya sehingga perawat harus mengkaji pola makan dan tidur pasien untuk mengetahui jika memang ada perubahan.

Gejala kesedihan mendalam dan depresi berat tidak ditemukan pada penelitian, melainkan responden telah asertif melanjutkan hidup, mampu berkomunikasi, dan mayoritas responden memiliki konsep diri yang baik. Hal tersebut dapat disebabkan semua responden pada penelitian ini telah mendapatkan pelayanan kesehatan dan konseling serta tergabung dalam kelompok dukungan sebaya. Hal tersebut dapat meningkatkan konsep diri pada perempuan dengan HIV positif.

Sesuai dengan penelitian yang menyatakan kelompok dukungan sebaya dapat meningkatkan kepercayaan diri, tingkat pengetahuan akan HIV, memudahkan akses ke pelayanan HIV, dan kegiatan positif lainnya (Handayani, 2011). Selain itu, penelitian lain juga menyebutkan bahwa banyak penderita HIV positif melaporkan dengan adanya konseling dari tenaga kesehatan membantu ODHA mempunyai koping sehingga dapat menerima kenyataan tentang hasil status HIV positif (Adedimeji, Alawode, \& Odutolu, 2010).

Kesedihan mendalam maupun depresi sering dialami oleh perempuan HIV positif namun intensitasnya dapat dikurangi dengan adanya dukungan orang terdekat, tenaga kesehatan 
dan sesama penderita HIV positif. Konseling dan informasi yang adekuat dan tepat dapat membantu perempuan HIV positif melanjutkan hidup dan patuh akan pengobatan. Selain itu, kelompok dukungan sebaya dapat menjadi role model bahwa penderita HIV AIDS masih dapat bertahan hidup bahkan terlihat sehat dan mampu beraktivitas seperti biasa.

Fase Acceptance. Perempuan HIV positif pada penelitian memiliki skala penerimaan penuh. Penelitian sebelumnya menyebutkan level penerimaan yang rendah berhubungan dengan sikap menyalahkan diri sendiri pada perempuan HIV positif (Tartakovsky \& Hamama, 2012). Sementara penerimaan yang tinggi akan status HIV positif berhubungan dengan koping spiritual yang digunakan (Lyimo, et al., 2014).

Responden dalam penelitian menunjukkan bahwa skala penuh dapat disebabkan oleh nilai untuk menerima segala sesuatu dalam hidupnya. Sebagian besar perempuan dididik dalam nilai-nilai budaya yg ditanamkan sedari kecil bahwa perempuan diharapkan menerima takdirnya. Murtisari (2013) menyatakan setiap individu memiliki tanggung jawab moral untuk menjaga keharmonisan oleh karena itu mereka harus menerima takdir mereka, sama seperti nilai yang diyakini orang Jawa harus bisa narima atau menerima posisinya dalam hidup dan nasibnya dengan melanjutkan hidup dan bersyukur. Dengan demikian nilai tersebut dapat menyebabkan perempuan HIV positif menunjukkan sikap penerimaan penuh akan status HIV dan lebih memikirkan masa depan anak-anaknya.

Perempuan berperan tidak hanya sebagai individu melainkan pula sebagai seorang ibu yang menjaga anak-anaknya. Perempuan merasa khawatir mengenai perawatan anak-anaknya jika dirinya meninggal. Oleh sebab itu, perempuan HIV positif tetap melanjutkan hidup bagi dirinya dan bagi kelangsungan hidup anak-anaknya. Damar dandu Plessis (2010) menyatakan perempuan HIV positif menerima takdir bahwa suaminya meninggal karena
AIDS dan dirinya pun terinfeksi HIV positif namun perempuan tetap melanjutkan hidupnya demi menjaga anaknya yang masih hidup. Demmer (2010) menyatakan perempuan HIV positif di Afrika Selatan berjuang menafkahi anak-anaknya dan melindungi mereka dari stigma HIV.

Selain nilai menerima takdir, perempuan HIV positif mampu menerima statusnya dapat disebabkan oleh adanya dukungan sosial dari tenaga kesehatan. Penelitian sebelumnya menyatakan perempuan HIV positif di India memiliki beban ganda untuk merawat anak-anaknya, suaminya yang sakit, stigma, dan kesulitan ekonomi namun mampu menghadapi semua itu dengan efektif disebabkan adanya dukungan sosial dan koping religi (Sharma, 2012).

Perempuan HIV positif menerima status HIV positifnya karena beranggapan dirinya sama seperti orang sehat lainnya yang mampu beraktivitas sehari-hari seperti biasa dengan syarat pengobatan yang teratur dan menghindari perilaku berisiko. Keyakinan tersebut yang memudahkan perempuan HIV positif untuk menerima status HIVnya. Phiri, Haas, Msukwa, Tenthani, Keiser, dan Tal (2018) menyatakan perempuan HIV positif merasakan dirinya baikbaik saja dan kuat dan termotivasi melanjutkan ART karena mereka percaya pengobatan terbukti memperbaiki kesehatan mereka sendiri dan anak-anak mereka. Perempuan HIV positif mengalami pengalaman transformasi positif dan pendewasaan termasuk terkait dengan kesehatan, spiritualitas, penerimaan diri, dan kepercayaan diri (Teti, French, Bonney, \& Lightfoot, 2015).

Kepercayaan diri dan pikiran positif pada perempuan HIV positif umumnya dibentuk setelah bertemu dengan kelompok sebayanya dan konseling dengan tenaga kesehatan. Kondisi demikian justru membuat jumlah imunitas tubuh meningkat dan kualitas hidup penderita HIV positif menjadi lebih baik. Hal tersebut dapat dilihat dari kondisi umum responden 
yang terlihat baik karena seluruh responden berasal dari pasien rawat jalan yang telah mendapatkan pelayanan kesehatan dan mendapatkan dukungan sebaya.

\section{Kesimpulan}

Pada perempuan dengan HIV positif mendapatkan sikap menyangkal berada pada skala sedang, kemarahan pada skala ringan, kesedihan mendalam pada skala sedang, dan penerimaan pada skala yang mendekati penerimaan penuh. Responden pada penelitian ini adalah mayoritas ibu rumah tangga yang sumber penularan HIV berasal dari suaminya. Sebagian terdapat janda yang penghasilannya di bawah upah minimum regional (UMR) sehingga harus berjuang menghidupi dan merawat anak-anaknya. Selain itu, mayoritas responden telah terinfeksi HIV positif lebih dari satu tahun lamanya.

Sehubungan dengan semua responden adalah pasien pada poli VCT (Voluntary Counseling and Testing) di fasilitas pelayanan primer sehingga responden telah mendapatkan pelayanan konseling dan pengobatan. Hal ini menjadi salah satu hal yang berkontribusi mendukung penerimaan penuh pada responden. Namun demikian, masih diperlukan penelitian lanjut mengenai fator-faktor yang memengaruhi berduka (AT, HR, PN).

\section{Ucapan Terima Kasih}

Penelitian ini didanai Lembaga Pengelola Dana Pendidikan, Kementerian Keuangan Republik Indonesia. Ucapan terima kasih diucapkan kepada Pimpinan dan jajaran dari Suku Dinas Kesehatan Provinsi DKI Jakarta, Kepala Puskesmas beserta tenaga kesehatan di DKI Jakarta. Terima kasih luar biasa kepada Ikatan Perempuan Positif Indonesia, Yayasan Kotex, Yayasan Tegak Tegar, dan Yayasan Anak dan Perempuan yang telah membantu dalam pengambilan data.

\section{Referensi}

Adedimeji, A.A., Alawode, O.O., \& Odutolu, O. (2010). Impact of Care and Social Support on Wellbeing among people living with HIV/AIDS in Nigeria. Iran J Public Health, 39 (2), 30-38.

Boer, L.M., Daudey, L., Peters, J.B., Molema, J., Prins, J.B., \& Vercoulen, J.H. (2014). Assessing the stages of the grieving process in chronic obstructive pulmonary disease (COPD): validation of the Acceptance of Disease and Impairments Questionnaire (ADIQ). International Journal of Behavioral Medicine, 21 (3), 561-570.

Bormann, J.E., \& Carrico, A.W. (2009). Increases in positive reappraisal coping during a group-based mantram intervention mediate sustained reductions in anger in HIVpositive persons. International Journal of Behavioral Medicine, 16 (1), 74-80.

Damar, A.P., \& du Plessis, G. (2010). Coping versus grieving in a "death-accepting" society: AIDS-bereaved women living with HIV in Indonesia. Journal Of Asian And African Studies, 45(4), 424-431.

Demmer, C. (2010). Experiences of women who have lost young children to AIDS in KwaZulu-Natal, South Africa: a qualitative study. Journal of the International AIDS Society, 13, 50.

Dewi, Y.I., Setyowati, S., \& Afiyanti, Y. (2008). Stres dan koping perempuan hamil yang didiagnosis HIV AIDS di DKI Jakarta: Studi grounded theory. Jurnal Keperawatan Indonesia, 12 (2), 121-128. doi: 10.7454/jki.v12i2.210.

Handayani, S. (2011). Peran dukungan sebaya terhadap mutu hidup ODHA di Indonesia Tahun 2011 (Studi Kualitatif di 10 Propinsi). Jakarta: Fakultas Ilmu Kesehatan Universitas Muhammadiyah Prof Dr. Hamka. Retrived from https://lemlit.uham ka.ac.id/index.php/berita/artikel-penelitian/9 3-06012012104405/peran-dukungan-sebaya. 
Kaplan, R. L. (2011). Living with HIV/AIDS in Lebanon: Women's Perceptions of Meaning (Dissertations and Theses). University of California, Los Angeles, Ann Arbor.

Kementerian Kesehatan. (2014). Situasi dan analisis HIV AIDS. Jakarta: Kementerian Kesehatan RI.

Leombruni, P., Fassino, S., Lavagnino, L., Orofino, G., Morosini, P., \& Picardi, A. (2009). The role of anger in adherence to highly active antiretroviral treatment in patients infected with HIV. Psychotherapy and Psychosomatics, 78 (4), 254-257.

Lyimo, R.A, Stutterheim, S.E., Hospers, H.J., de Glee, T., van der Ven, A., \& de Bruin, M. (2014). Stigma, disclosure, coping, and medication adherence among people living with HIV/AIDS in Northern Tanzania. AIDS Patient Care and STDs, 28 (2), 98-105.

Murtisari, E.T. (2013). Some Traditional Javanese Values in NSM: From God to Social Interaction. International Journal of Indonesian Studies. 1, 110-125.

Phiri, N., Haas, A.D., Msukwa, M.T., Tenthani, L., Keiser, O., \& Tal, K. (2018). "I found that I was well and strong": Women's motivations for remaining on ART under option $\mathrm{B}+$ in Malawi. PLoS One, 13 (6), e0197854. doi: 10.1371/journal.pone.0197854.

Piper, K., Enah, C., \& Daniel, M. (2014). Black southern rural adolescents' HIV stigma, denial, and misconceptions and implications for HIV prevention. J Psychosoc Nurs Ment Health Serv, 52 (6), 50-56.

Rahmalia, A., Wisaksana, R., Meijerink, H., Indrati, A.R., Alisjahbana, B., Roeleveld, N., ... van Crevel, R. (2015). Women with HIV in Indonesia: Are they bridging a concentrated epidemic to the wider community? BMC Research Notes, 8 (1), 757.
Sharma, N. (2012). Role of coping styles in quality of life of people living with HIV/AIDS, 3 (1), 6-9.

Tartakovsky, E., \& Hamama, L. (2012). Mothers of children infected with HIV: How mothers' cognitive coping strategies are related to their psychological distress and acceptance of their children. Cognitive Therapy and Research, 36 (6), 681-684.

Teti, M., French, B., Bonney, L., \& Lightfoot, M. (2015). "I created something new with something that had died": Photo-narratives of positive transformation among women with HIV. AIDS and Behavior, 19 (7), 12751287. doi:http://dx.doi.org/10.1007/s10461015-1000-7.

Videbeck, S.L. (2011). Psychiatric-mental health nursing (5th Ed.). Philadelphia: Wolters Kluwer, Lippincott Williams \& Wilkins.

Walulu, R.N. (2007). Mothers living with HIV disease: A grounded theory study (Master's Thesis). Available from Nursing \& Allied Health Database; ProQuest Dissertations \& Theses Global (304733896). Retrieved from https://search.proquest.com/docview/304733 896 ? accountid=17242.

Word Health Organization. (2015). HIV AIDS. Retrieved from http://www.who.int/media centre/factsheets/fs360/en/

Wringe, A., Roura, M., Urassa, M., Busza, J., Athanas, V., \& Zaba, B. (2009). Doubts, denial and divine intervention: Understanding delayed attendance and poor retention rates at a HIV treatment programme in rural Tanzania. AIDS Care, 21 (5), 632637. 